\title{
Revisit Intention Regression Model of Agritourism Destinations of Pelaga and Buyan-Tamblingan, Bali, Indonesia
}

\author{
I GustiBagus Rai Utama ${ }^{a}$, ChristimuliaPurnama Trimurti ${ }^{\text {b }}$, Ni PutuDyahKrismawintari ${ }^{\mathrm{c}}$, I \\ WayanRuspendiJunaedi ${ }^{\mathrm{d}}$ \\ a,b,c,d UniversitasDhyanaPura, Bali. Indonesia. \\ Corresponding Email: raiutama@undhirabali.ac.id
}

\begin{abstract}
This investigation was driven in Pelaga and Buyan-Tamblingan Area was organized using a research study that about 500 respondents for the start of 2020 and dictated by an accidental sampling method. The statistical analysis uses multiple linear regression, ANOVA, and R square to make an investigation conclusion. Main findings are simultaneously predictors variables consisting of beautiful scenery, most recently facilities, unique attractions, completeness of facilities, close distance, easy transportation, easy to reach location, and community hospitality significantly influence variable dependent intention to visit with influence strength of the determinant value at 0.539 or $53.9 \%$. This study will enable the marketing practitioners to better understand the motivation of visitors to visit agritourism areas. Some predictor variables that significantly influence the intention to visit are the latest facilities, unique attractions, easy to reach location, and community hospitality.
\end{abstract}

Keywords: tourism, agritourism, tourist destination, unique attractions, community hospitality

\section{Introduction}

The dynamic of business is an arranged activity to sift through the advantages of the movement business, give and market get-away goals, travel industry office associations, and various associations that are related to the movement business. The movement business is one of the principal drivers of the world economy which is demonstrated to have choices to expand the development of a nation. The advancement of the movement business can drive businesses preparing to give social, and money-related vicinity to a country. Exactly when the movement business is very much managed, it must have the choice to profit the system at a goal. The accomplishment of the movement business as far as government income from the movement business section can bolster different fields (Mitas, et al., 2017; Utama and Mahadewi, 2012; Choi, 2015).

In developing countries with a diversity of flora and fauna, such as Indonesia, including tourism in the protected area management strategy is seen as desirable, especially from the perspective of economic development. While maximizing economic benefits is an important and primary goal, it still takes into account the sustainability of an area, as a resilient social-ecological system. A strong socio-ecological system is believed to be better able to absorb and adapt to disturbances while maintaining its natural basic functions. The presence and growth of tourism add complexity to various social and ecological components and presents additional challenges for regional governance. The governance is influenced by the perceptions of tourists who have an interest in the realization of a better quality travel experience (Pedju and Orams, 2013; Arismayanti, et al, 2017; Utama, 2014).

Further exploring tourist perceptions of the management of tourist attraction in protected conservation areas is very important, according to Picard (2008) proposer that tourism development must be understood not as a disturbance from external forces that attack Bali from outside, but as the process of changing from in Balinese society. This is because Balinese culture is a product of a dynamic process with the outside world, not only limited to tourists, but also to artists and intellectuals who also contribute to compiling Bali's tourism image. He proposed that what should be focused on cultural tourism and to convince the Balinese people that they have a culture that must be maintained because it is something valuable. On the other hand, culture has been manipulated and adapted by the tourism industry; their culture is not only a source of profit and pride but also a cause of anxiety for Balinese, who are starting to wonder if they are still native to Bali. This research will be the basis for considerations to act for the development of tourism that borders directly or indirectly with conservation areas owned by Bali today (Utama, 2016). 


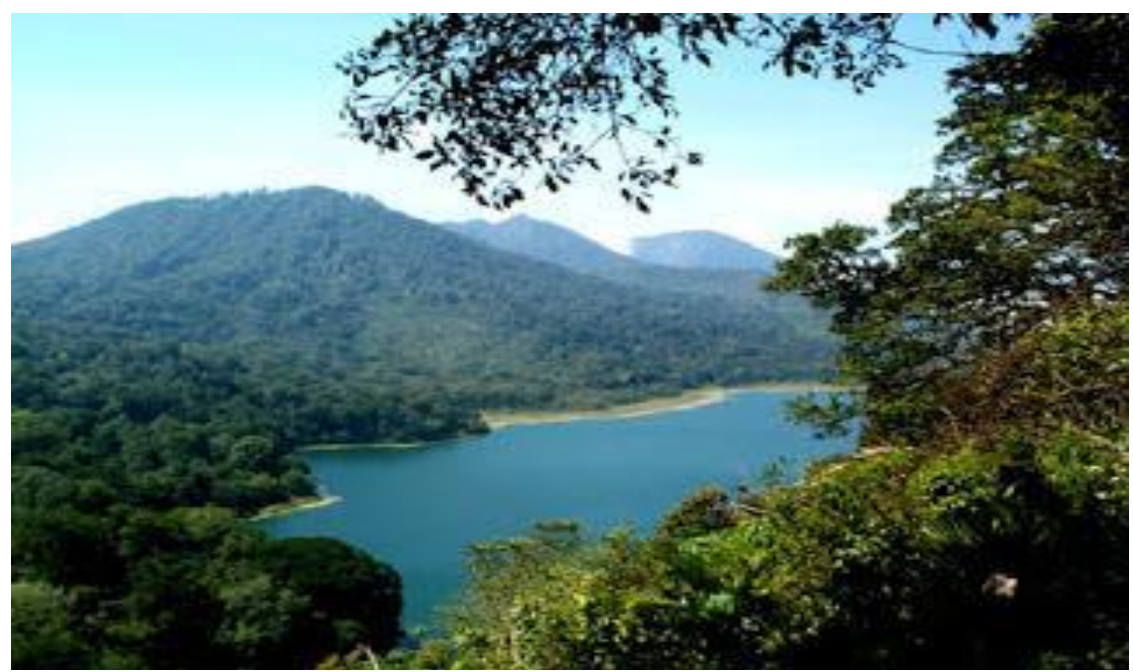

Figure 1.Buyan-Tamblingan Area. The photo was taken by TripAdvisor

This research tries to trace tourist perceptions about tourism development in areas namely BuyanTamblingan (see Fig. 1) and PucakMangu-Pelaga Regions (see Fig 2), both of which have similarities, which have natural beauty and some sacred areas in the form of temples. The Buyan-Tamblingan area is supported by the beauty of nature and the authenticity of forest conservation and the uniqueness of people's gardens in the form of native flowers and citrus orchards. The garden is managed professionally by developing an agritourism model. The best prospective alternative for diversifying the agricultural sector can improve people's welfare (Utama, 2017; Utama and Junaedi, 2015).

The subsequent territory is PucakManguPelaga is in the good countries with a height of $1017 \mathrm{~m}$ above ocean level. It is situated on a bumpy green level and has a low degree of contamination. This town is additionally broadly utilized as an elective course from Denpasar to Batur which goes through the Sangeh vacation spot. Pelaga Village offers numerous agritourism attractions complete with its environment. The topography of this town is a good country and has agreeable temperatures. What's more, Pelaga has wide and various plant ranches, going from vegetables, espresso, vanilla, corn. Those zones have a lovely, agreeable environment, which the possibility to be created as an ecotourism town (Junaedi and Utama, 2017).

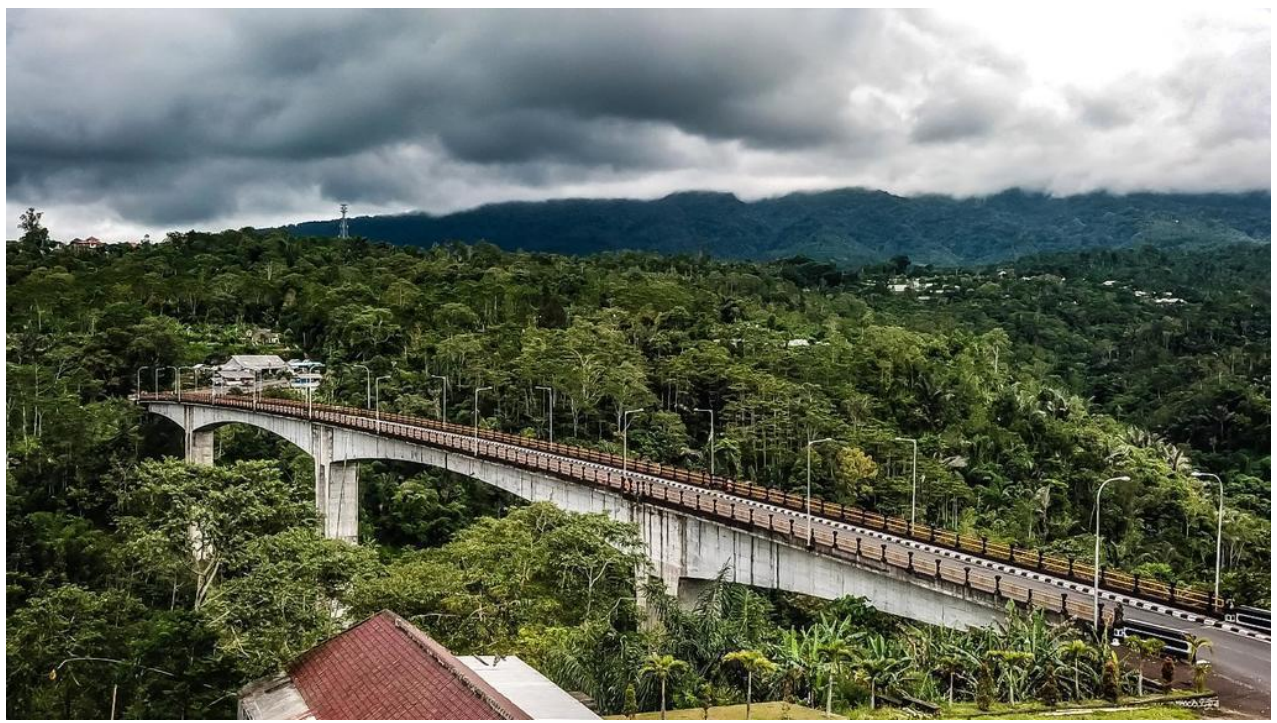

Figure 2.Pelaga Area, Bali. The photo was taken by GPS Wisata Indonesia

There are two utilize the standard of agritourism industry development which is relied upon to goodly affect some moral worth plans applied, while the morals are: (1) Nature, that is the common zone so the threat that should 
be kept up with the idea of reasonable the travel industry is acknowledged for the people to come. (2) The uniqueness of this locale with cold temperatures consistently, with the exceptional common view, must be kept up and saved instead of misused. (3) Scarcity, which is protection timberland that extends along a traveler park, is something that is viewed as uncommon right now; the idea of conservation of nature must keep on being done with the goal that this territory will keep on pulling in constantly. (4) Optimizing Land Use: ranchers can thrive on the off chance that they make a blend of items with the improvement of the agritourism industry that can be of twofold an incentive by consolidating the agrarian segment and the travel industry part. (5) Manpower association, which is a huge piece of the network around the zone of agrarian occupations, and the advancement of agritourism can include rustic networks (Junaedi and Utama, 2017; Pedju, 2018; Utama and Trimurti, 2019).

The aim of the research: Based on the phenomenon, this study considers that researching the perception toward the Development of Agritourism Destination from the Visitor Perspective. The purpose of this study is to design agritourism development models in line with the expectations of the visitors.

Problems statement: The relationship between predictors variables (X1) Beautiful Scenery, (X2) Facilities most recently, (X3) Unique Attraction, (X4) Completeness of Facilities, (X5) Close Distance, (X6) Easy Transportation, (X7) Location Easy to reach, (X8) Community Hospitality, with Dependent Variable (Y) Intention to Visit.

Research Objectives: To determine the relationship between predictors variables (X1) Beautiful Scenery, (X2) Facilities most recently, (X3) Unique Attraction, (X4) Completeness of Facilities, (X5) Close Distance, (X6) Easy Transportation, (X7) Location Easy to reach, (X8) Community Hospitality, with Dependent Variable (Y) Intention to Visit.

\section{Literature Review}

\subsection{The principles of sustainable development}

Tourism, whatever its type and name, should be built and developed based on the principles of sustainable development by the United Nations, 2002 (in Junaedi and Utama, 2015). The first principle is that tourism development must be built by involving local communities; the vision of tourism development should be designed based on the ideas of local communities and for the welfare of local communities. The second principle is to create a balance between the needs of tourists and the community (Krismawintari and Utama, 2019).

The importance of community economic empowerment is a goal based on the willingness to shape the quality of the destinations expected by tourists. The third principle is that development must involve stakeholders, and involving more parties will get better input. The involvement of stakeholders must be able to accommodate the opinions of local community organizations, involve poor communities, involve women, involve tourism associations and other groups in the community that has the potential to influence the course of development.

The fourth principle is, providing convenience to local entrepreneurs on a small and medium scale. Education programs related to tourism must prioritize the local population and the industries that develop in the region must be able to accommodate as many local workers as possible. The fifth principle is, tourism must be conditioned for generating other businesses in the community, which means that tourism must have a multiplier impact on other sectors, both new businesses, and businesses that have developed at this time. The sixth principle is that there is cooperation between the local communities as creators of tourist attractions with the operators of tour package sellers, so it is necessary to build mutually beneficial cooperation relationships.

The seventh principle is that tourism development must be able to guarantee sustainability, provide benefits to today's society and not harm future generations. It is logical to assume that tourism development has the potential to damage the environment if it is associated with an increase in tourist numbers and the degradation of tourism destinations (Hunter and Green, 1995). This relationship is a concept of carrying capacity that shows a management approach that allows growth within acceptable limits (Johnson and Thomas, 1996; Krismawintari and Utama, 2019).

The eighth principle is that tourism must grow on the principle of optimization, not on exploitation. The capacity management strategy will be the best choice, although at present there is still considerable controversy. This concept is a need that should be recognized to limit and control the dimensions of tourism development that can threaten the continued use of limited resources, at the same time; the concept is faced with the desire to maximize opportunities as growth goals and realize potential benefits associated with visitors which is increasing. The ninth principle is that there must be periodic monitoring and evaluation to ensure that tourism development continues in the concept of sustainable development.

The tenth principle is that openness to the use of resources such as underground water use, land use, and other resource use must be ensured not to be misused. For this reason, the code of ethics for sustainable tourism 
development must be formulated and become an agenda that is continually revised and even the latest revision was held in Bali by UNWTO Etic Code, 2011 (in Marcinek, 2017). The eleventh principle is to carry out programs to improve human resources in the form of education, training, and certification for the field of tourism expertise so that workers can be prepared to work following the assigned job descriptions following their respective fields so that the certification program will be the right choice. Certification as a process for raising industry standards has supporters and values of criticism.

This section reviews the feasibility of certification as a policy tool for making improvements voluntarily, under five aspects: fairness, effectiveness, efficiency, credibility, and integration (Font, et al, 2003; Frolova, et al., 2019). The twelfth principle is the realization of three qualities namely tourism must be able to realize the quality of life of the local community, on the other hand, tourism must be able to provide business quality to service providers in the tourism industry and the next and the most important is the creation of quality tourist experiences. The success of the travel industry improvement can be seen by expanding in the number of traveler appearances from period to period (Sagala, et al., 2019)

Extending the number of explorers can be recognized whether tourists who have visited are content with the objective, and various qualities offered by the chief (Choi and Sirakaya, 2005). Satisfied voyagers will all in all be devoted to going over their outings later on, and empower them to endorse their partners and relatives to go to a comparative spot (Shukla and Saxena, 2019). The marvel that occurs in the movement of business designs, especially on the planet today is the speedy advancement of agritourism that can be made in a couple of areas in Bali, Indonesia, and incorporating locales (Junaedi and Utama, 2017).

\subsection{The tourism product}

When all is said in done, from the perspective of the administration and the network that the quality travel industry will (1) carry financial advantages to the administration, (2) become a potential market for merchandise and ventures identified with the travel industry, (3) acquire extra pay that is straightforwardly or legitimately related in a roundabout way with the movement business, (4) extending employment opportunities, both in related and by implication related fragments, (5) new wellsprings of vocation, and (6) driving the workmanship business (Putra, 2015) and (Constantino, et al, 2016). From a visitor's point of view, they trust that (1) the nearness of get-away spots identified with the agritourism industry can be a decision fascination for a get-away. (2) The accessible offices that are required can be as extra open offices, media communications, lodgings, and eateries in advertisement focuses. (3) The foundation alluded to is accessible as water system frameworks, correspondence systems, wellbeing offices, transportation terminals, vitality and power sources, waste or water removal frameworks, streets, and security frameworks. (4) Available open transportation, Bus-Terminal, traveler wellbeing framework, travel data framework, Labor, toll assurance, vacationer maps. (5) Community cordiality will be an impression of the achievement of a decent travel industry framework (Sunaryo and Suyono, 2013); (Sutawa, 2012); (Ha, et al, 2016).

\section{Research Method}

This exploration was led in Pelaga and Buyan-Tamblingan Area was structured utilizing a research study that included 500 respondents at the beginning of 2020 and determined by accidental sampling technique because there are no numbers available in the visitor population (Utama and Mahadewi, 2012). Descriptive statistics, multiple linear regression, ANOVA, and R square analysis are used to make research conclusions (Utama and Mahadewi, 2012).

The research instrument in the form of a confirmatory questionnaire about several influential aspects that will be asked to the respondents as follows: (X1) Beautiful scenery, (X2) Latest facilities, (X3) Unique Attraction, (X4) Completeness of Facilities, (X5) Close Distance, (X6) Easy Transportation, (X7) Location Easy to reach, (X8) Community Hospitality, (Y) Intention to Visit (Wang, 1999); (Gardiner and Scott, 2018; Utama and Trimurti, 2020).

\section{Results and Discussions}

The vacationer offices that can be utilized by guests include (1) Hiking that permits guests to stroll to investigate all types of magnificence that exist right now both characteristic view and the excellence of ranches comprising vegetables, organic product, blossoms, and fish in the lake. (2) Tour visiting property utilizing carriage. (3) Cycling should be possible outside the Agri locale, which is around them. (4) See and appreciate different sorts of 
feathered creatures that additionally live here. (5) Children play area, which is explicitly given by the agritourism to the individuals who come joined by their kids. (6) Some of the cascades and lakes (Utama and Trimurti, 2020).

\subsection{Respondent's profile}

In the point of view of Profession (see Table 1) associated with this examination, it demonstrates that understudy appears to be increasingly prevailing taking part in the overview with an extent of $83.6 \%$, and Private workers at $8.4 \%$, Government representatives at $5.6 \%$, and Businessman at $2.4 \%$. This measurable information shows that guests to this agritourism industry fascination are overwhelmed by understudies or twenty to thirty-yearolds. Those who participated in this survey were predominantly from Bali and it can be estimated that they were students who were less than 20 years old at around $86.4 \%$, and some of them were from outside Bali around $13.6 \%$ (see Table 1). This statistical data indicates that the attraction of agritourism is more in demand by visitors who come from within the Province of Bali.

Table 1 Respondent's Profile

\begin{tabular}{|c|c|c|c|}
\hline Profile & & Frequency & Percent \\
\hline \multirow[t]{5}{*}{ Profession } & Government employees & 28 & 5.6 \\
\hline & Private employees & 42 & 8.4 \\
\hline & Student & 418 & 83.6 \\
\hline & Businessman & 12 & 2.4 \\
\hline & Total & 500 & 100.0 \\
\hline \multirow[t]{3}{*}{ Domicile } & Outside Bali & 68 & 13.6 \\
\hline & Around Bali & 432 & 86.4 \\
\hline & Total & 500 & 100.0 \\
\hline \multirow[t]{6}{*}{ Aging Group } & 21-30 years & 108 & 21.6 \\
\hline & $31-40$ years & 34 & 6.8 \\
\hline & $41-50$ years & 18 & 3.6 \\
\hline & Less than 20 years & 326 & 65.2 \\
\hline & More than 50 years & 14 & 2.8 \\
\hline & Total & 500 & 100.0 \\
\hline
\end{tabular}

In the point of view of the maturing gathering of the respondent (see Table 1), it shows that the individuals who took an interest right now to be more prevailing by they are under 20 years with an extent of $65.2 \%$, at that point $21.6 \%$ of them are 21-30 years, somewhere in the range of 31 and 45 years of age at $6.8 \%$, somewhere in the range of 41 and 50 years at $3.6 \%$, and a little rate and more than 50 years of age at $2.8 \%$. This measurable information additionally shows that guests to this agritourism industry fascination are ruled by those matured less than 20 years who are delegated millennials.

Table 2 Perception of Descriptive Statistics

\begin{tabular}{lcc}
\hline Indicator & Mean & Std. Deviation Remark \\
\hline (X1) Beautiful scenery & 4.21 & .733 Very Good \\
(X2) Latest facilities & 4.22 & .688 Very Good \\
(X3) Unique Attraction & 4.21 & .684 Very Good \\
(X4) Completeness of Facilities & 4.17 & $.695 \mathrm{Good}$ \\
(X5) Close Distance & 4.01 & $.742 \mathrm{Good}$ \\
(X6) Easy Transportation & $.736 \mathrm{Good}$ \\
(X7) Location Easy to reach & 4.05 & $.738 \mathrm{Good}$ \\
(X8) Community Hospitality & 4.12 & $.687 \mathrm{Good}$ \\
(Y) Intention to Visit & 4.22 & .651 Very Good \\
\hline
\end{tabular}

Valid N (listwise) $=500$

Remark: $(1,00-1,80=$ Very bad $),(1,81-2,60=$ bad $),(2,61-3,40=$ Average $),(3,41-4,20=$ Good $),(4,21-5,00$ = Very Good) 


\subsection{Visitor's perception}

The results of a survey of 500 respondent's perception about Agritourism (see Table 2) can be seen as overall of variables that consist of very good perception those are (X1) beautiful scenery, (X2) latest facilities, (X3) unique attraction, and (Y) intention to visit. Some of them have a good perception of (X4) completeness of facilities, (X5) close distance, (X6) easy transportation, (X7) location easy to reach, and (X8) community hospitality.

The results of this statistical analysis also indicate that the appeal of agrotourism is identical to having beautiful scenery, the latest facilities available, having unique attractions, and ultimately always causing intention to visit. This finding also in line with the research suggests that stated by Sunaryo and Suyono, (2013), and Sutawa, (2012) where visitor perspective, they hope that (1) the existence of vacation spots related to agro-tourism can be natural beauty. (2) The available facilities that are needed can be in the form of additional public facilities that visitors need (3) Adequate infrastructure for a vacation (4) Public transportation is available, and other types of transportation (5) Hospitality of the local community (Utama and Trimurti, 2019).

\subsection{The regression analysis}

In this study, the variables analyzed were independent variables or predictors: (Constant), (X1) Beautiful Scenery, (X2) Facilities most recently, (X3) Unique Attraction, (X4) Completeness of Facilities, (X5) Close Distance, (X6) ) Easy Transportation, (X7) Location Easy to reach, (X8) Community Hospitality, and Dependent Variable: (Y) Intention to Visit.

Table 3 The Regression Analysis Output

\begin{tabular}{|c|c|c|c|c|c|}
\hline \multirow[b]{2}{*}{ Model } & \multicolumn{2}{|c|}{ Unstandardized Coefficients } & Standardized Coefficients & \multirow[b]{2}{*}{$\mathrm{t}$} & \multirow[b]{2}{*}{ Sig. } \\
\hline & B & Std. Error & Beta & & \\
\hline (Constant) & .744 & .149 & & 5.006 & .000 \\
\hline (X1) Beautiful scenery & .073 & .040 & .08 & 1.818 & .070 \\
\hline (X2) Latest facilities & .132 & .046 & .13 & 2.867 & .004 \\
\hline (X3) Unique Attraction & .169 & .043 & .17 & 3.930 & .000 \\
\hline (X4) Completeness of Facilities & .076 & .044 & .08 & 1.714 & .087 \\
\hline (X5) Close Distance & .070 & .037 & .08 & 1.871 & .062 \\
\hline (X6) Easy Transportation & -.007 & .042 & -.00 & -.174 & .862 \\
\hline (X7) Location Easy to reach & .185 & .044 & .21 & 4.168 & .000 \\
\hline (X8) Community Hospitality & .142 & .045 & .15 & 3.171 & .002 \\
\hline
\end{tabular}

a. Dependent Variable: (Y) Revisit Intention

The results of the analysis produce the following regression models:

$$
Y=0.744+0.073 X_{1}+0.132 X_{2}+0.169 X_{3}+0.076 X_{4}+0.070 X_{5}-0.007 X_{6}+0.185 X_{7}+0.142 X_{8} \ldots \ldots \text { (1) }
$$

There is a regression coefficient $(\mathrm{b} 6=-0.007)$ that is negative, this can indicate that the easier the transportation, the more attractive the attraction of agritourism to be visited. While the other positive values are (b1) beautiful scenery, (b2) latest facilities, (b3) unique attractions, (b4) completeness of facilities, (b5) close distance, (b7) location easy to reach, and (b8) community hospitality which means that the development of these variables will have a positive impact on the interest of a return visit.

Table 4 Analysis of Variance (ANOVA)

\begin{tabular}{llrrrrr}
\hline Model & & Sum of Squares & df & Mean Square & F & Sig. \\
\hline 1 & Regression & 113.822 & 8 & 14.228 & 71.711 & $.000^{\mathrm{b}}$ \\
& Residual & 97.416 & 491 & .198 & & \\
& Total & 211.238 & 499 & & & \\
\hline
\end{tabular}

a. Dependent Variable: (Y) Intention to Visit

b. Predictors: (Constant), (X1) Beautiful Scenery, (X2) Facilities most recently, (X3) Unique Attraction, (X4) Completeness of Facilities, (X5) Close Distance, (X6) Easy Transportation, (X7) Location Easy to reach, (X8) Community Hospitality, and Dependent Variable: (Y) Intention to Visit. 
The basis for determining the Independent Test $\mathrm{T}$ is based on the significance value (2-tailed) that measures the presence or absence of an average difference in the subjects tested. Significance value (2-tailed)> 0.05 indicates that there is no average difference between study subjects. The results of this multiple linear regression analysis prove that (see Table 3):

(X1) beautiful scenery does not affect $(\mathrm{Y})$ intention to visit because the significance value is greater $(0.070)$ than 0.05

(X2) latest facilities affect $(\mathrm{Y})$ intention to visit as evidenced by the significance value is smaller $(0.004)$ from 0.05

(X3) unique attraction influences $(Y)$ intention to visit as evidenced by its significance value is smaller $(0,000)$ than 0.05

(X4) completeness of facilities does not affect $(\mathrm{Y})$ intention to visit because the significance value is greater $(0.87)$ than 0.05

(X5) close distance does not affect $(\mathrm{Y})$ intention to visit because the significance value is greater (0.062) than 0.05

(X6) easy transportation no effect on (Y) intention to visit because the significance value is greater $(0.864)$ than 0.05

(X7) location easy to reach effects $(Y)$ intention to visit as evidenced by the significance value is smaller $(0,000)$ than 0.05

(X8) community hospitality effects $(\mathrm{Y})$ intention to visit as evidenced by the significance value is smaller $(0.002)$ from 0.05

If seen from the significance value (sig), it can be concluded that four variables do not affect tourist return visits, among them are (X1) Beautiful scenery, (X4) Completeness of Facilities, (X5) Close Distance, and (X6) Easy Transportation. While four other variables are stated to have a significant effect on repeat visits, namely (X2) Latest facilities, (X3) Unique Attraction, (X7) Location Easy to reach, and (X8) Community Hospitality.

ANOVA Test or Analysis of Variance (ANOVA) was developed to enable researchers to test the comparison hypotheses of more than two groups (see Table 4).

ANOVA analysis results prove that the Predictors variable: (X1) Beautiful Scenery, (X2) Facilities most recently, (X3) Unique Attraction, (X4) Completeness of Facilities, (X5) Close Distance, (X6) Easy Transportation, (X7) Location Easy to reach, (X8) Community Hospitality have a significant simultaneous effect on Dependent Variable: (Y) Intention to Visit as evidenced by the sig $(0,000)$ value less than 0.05 (see Table 4).

Table 5 The Coefficient of Determination

\begin{tabular}{rrrrr}
\hline Model & $\mathrm{R}$ & $\mathrm{R}$ Square & Adjusted R Square & Std. An error of the Estimate \\
\hline 1 & $.734^{\mathrm{a}}$ & .539 & .531 & .445 \\
\hline
\end{tabular}

a. Predictors: (Constant), (X1) Beautiful Scenery, (X2) Facilities most recently, (X3) Unique Attraction, (X4) Completeness of Facilities, (X5) Close Distance, (X6) Easy Transportation, (X7) Location Easy to reach, (X8) Community Hospitality, and Dependent Variable: (Y) Intention to Visit.

Determinant analysis results prove that the predictors variable: (X1) Beautiful Scenery, (X2) Facilities most recently, (X3) Unique Attraction, (X4) Completeness of Facilities, (X5) Close Distance, (X6) Easy Transportation, (X7) Location Easy to reach, (X8) Community Hospitality has a medium simultaneous effect on Dependent Variable: (Y) Intention to Visit as evidenced by the R Square (0,539 or 53.9\%) value less than 0.05 (see Table 5).

\section{Conclusion, Limitation, and Suggestions}

\subsection{Conclusions}

Simultaneously Predictors variables consisting of beautiful scenery, most recent facilities, unique attractions, completeness of facilities, close distance, easy transportation, easy to reach location, and community hospitality significantly influence variable dependent intention to visit with influence strength of the determinant value at 0.539 or $53.9 \%$.

If seen partially, only some predictor variables that significantly influence the intention to visit are the latest facilities, unique attractions, easy to reach location, and community hospitality. However, other predictor variables such as beautiful scenery, completeness of facilities, close distance, and easy transportation have no significant effect on the intention to visit. ANOVA analysis results prove that the predictor's variable, namely beautiful scenery, facilities most recently, unique attraction, completeness of facilities, close distance, easy transportation, location easy to reach, community hospitality has a significant simultaneous effect on dependent variable intention to visit as evidenced by the sig $(0.000)$ value less than 0.05 . 


\subsection{Limitation, and Suggestions}

Limitations and suggestions are some variables that need to be increased again because the image is not optimal, some of them have a good perception of completeness of facilities, close distance, easy to reach location, and community hospitality, except easy transportation because this variable is beyond the reach of the tourist attraction manager. Stakeholders should pay attention to the latest facilities, unique attractions, easy to reach locations, and community hospitality because they significantly influence the intention of a return visit (Trimurti and Utama, 2020; Utama and Junaedi, 2015). The perception of tourists also needs to be considered in the management of tourist attractions where tourists have a very good perception of their image, beautiful scenery, latest facilities, and unique attractions (Pratiwi, et al., 2018; Trimurti and Utama, 2020)

\section{Acknowledgment}

This research is funded by The Ministry of Research and Higher Education of the Republic of Indonesia, through the Fundamental Research Grant for the monetary year 2019-2020.

\section{References}

6. Arismayanti, N.K., Widyatmaja, I.G.N., Wiraatmaja, I.W., (2017). The Establishment of Rural Tourism Based Creative Economy in Kendran Village, Gianyar. Udayana Journal of Social Sciences and Humanities, p.11.

7. Choi, H.S.C., Sirakaya, E., (2005). Measuring residents' attitude toward sustainable tourism: Development of sustainable tourism attitude scale. Journal of Travel Research, 43(4), pp.380-394.

8. Choi, S. H., \& Fu, X. (2015). Re-examining the dimensionality of leisure motivation and leisure satisfaction in a multicultural context: Evidence from Macau. Humanities \& Social Sciences Reviews, 3(1), 06-10.

9. Constantino, H.A., Fernandes, P.O. and Teixeira, J.P., (2016). Tourism demand modeling and forecasting with artificial neural network models: The Mozambique case study. Tékhne, 14(2), pp.113-124.

10. Font, X., Sanabria, R. and Skinner, E., (2003). Sustainable tourism and ecotourism certification: Raising standards and benefits. Journal of ecotourism, 2(3), pp.213-218.

11. Frolova, E. V., Rogach, O. V., \&Ryabova, T. M. (2019). Tourism Attraction in Russian Regions in Cyberspace: New Tendencies of Tourism Media Marketing. Humanities \& Social Sciences Reviews, 7(4), 857-862.

12. Gardiner, S., \& Scott, N. (2018). Destination Innovation Matrix: A framework for new tourism experience and market development. Journal of Destination Marketing \& Management, 10, 122-131.

13. Ha, T.M., Bosch, O.J., and Nguyen, N.C., (2016). A participatory systemic approach to rural community development in Vietnam. International Journal of Scientific \& Technology Research Volume 5, Issue 04, April 2016, pp.53-61.

14. Hunter, C. and Green, H., (1995). Tourism and the environment: A sustainable relationship? Routledge.

15. Johnson, P. and Thomas, B., (1996). Tourism capacity: a critique.

16. Junaedi, I.W.R., and Utama, I.G.B.R., (2017). Agrotourism is the economic transformation of the tourism village in Bali (case study: Blimbingsari Village, Jembrana, Bali). Journal of Business on Hospitality and Tourism, 2(1), pp.10-24.

17. Krismawintari, NPD., Utama, IGBR. (2019). KajiantentangPenerapan Community Based Tourism di Daya Tarik WisataJatiluwih, Tabanan, Bali. JurnalKajian Bali (Journal of Bali Studies) 9 (2), 429-448-429-448

18. Marcinek, A.A., (2017). Tourism in the Ecuadorian Amazon: Political Ecology, Cultural Commons, and Emic/Etic Understandings.

19. Mitas, O., Blapp, M., Gosana, D. and Frischknecht, A., (2017). Creative tourism in Bali's rural communities (by Manuela Blapp) \& Respond to Manuela Blapp (by DjinaldiGosana) \&" Respecting creativity": response to Manuela Blapp (by Astrid Frischknecht) \&" Smart growth or sweet dreams?": response to Manuela Blapp (by OndrejMitas). Tourism Destination Management Insights, 1(1), pp.19-24.

20. Pedju, F.M.K., (2018). Stakeholders' perceptions of the impacts of tourism on the social and ecological resilience of marine protected areas in Bali, Indonesia (Doctoral dissertation, Auckland University of Technology).

21. Picard, M. (2008). Balinese identity as a tourist attraction: From 'cultural tourism' (pariwisatabudaya) to 'Bali sustain' (ajeg Bali). Tourist Studies, 8(2), 155-173. doi:10.1177/1468797608099246 
22. Pratiwi, N. M. S., Komala, I. G. A. M. K., \&Suparta, I. K. (2018). The Marketing Mix Factors That Influence The Decision Of Guests To Visit In Sakura Restaurant At Melia Bali Indonesia. Journal of Applied Sciences in Travel and Hospitality, 1(2), 120.

23. Putra, I.N.D. (2015). PariwisataBerbasisMasyarakat Model Bali. Denpasar: Program Studi Magister KajianPariwisataUniversitasUdayana

24. Sagala, E. D., Ningsih, C., \&Turgarini, D. Analysis Of Influence Of Tourism And Branding Perceptions On Purchase Decisions (Study conducted in Chinatown as Halal Gastronomy in the City of Bandung). Gastronomy Tourism Journal, 5(2), 56-69.

25. Shukla, R., Singh, M., \&Saxena, S. (2019). Consumer Perception of Hospitality Services in JCI Accredited Hospitals at Delhi-NCR: An Exploratory Research on Growth of Medical Tourism. Humanities \& Social Sciences Reviews eISSN, 2395-6518.

26. Sunaryo, S. and Suyono, J., (2013). A test of the model of the relationship between public service motivation, job satisfaction, and organizational citizenship behavior. Review Integrative Business \& Economics, 2(1), p.384.

27. Sutawa, G.K., (2012). Issues on Bali tourism development and community empowerment to support sustainable tourism development. Procedia Economics and Finance, 4, pp.413-422.

28. Trimurti, ChristimuliaPurnama., Utama, I GustiBagus Rai. (2019). An Investigation Of Tourism Motivation And Tourist Attraction Of Tourists To Bali. JurnalManajemendanKewirausahaan 21 (2), 130-133

29. Trimurti, ChristimuliaPurnama., Utama, I GustiBagus Rai. (2020). The Examination Bali Destination Marketing Chain Model Based On Tourist Motivation. International Journal of Scientific \& Technology Research 9 (3), 4491-4495

30. Utama, I GustiBagus Rai., Trimurti, ChristimuliaPurnama. (2019). The Correlation Tourist Attraction with Revisit Intention of AgritourismPelagaBadung Bali, Indonesia. Petra International Journal of Business Studies 2 (2), 119-124

31. Utama, I GustiBagus Rai., Trimurti, ChristimuliaPurnama. (2020). Investigation of the Image of BuyanTamblingan Area as Tourist Attraction Destination. International Journal of Scientific \& Technology Research 9 (3), 5234-5238

32. Utama, I. G. B. R. (2014). The motivation and satisfaction of elderly tourists visiting Bali tourism destination Indonesia. Journal of Economics and Sustainable Development, 5(18), 1700-2222.

33. Utama, I. G. B. R. (2016). Destination Image of Bali Based On The Push Motivational Factors, Identity And Destination Creations In The Perspective Of Foreign Senior Tourists. JurnalManajemendanKewirausahaan, 18(1), 16-24.

34. Utama, I. G. B. R. (2017, August). Tourism Destination Image of Bali According to European Tourists. In 2nd International Conference on Innovative Research Across Disciplines (ICIRAD 2017). Atlantis Press.

35. Utama, I.G.B.R, Mahadewi, N.M.E. (2012). MetodologiPenelitianPariwisata Dan Perhotelan. 1 ed. Yogyakarta: Penerbit Andi.

36. Utama, I.G.B.R., Junaedi, I.W.R., (2015). AgrowisatasebagaiPariwisataAlternatif Indonesia. 1 ed. Yogyakarta: PenerbitBukuDeepublish Yogyakarta CV. BUDI UTAMA.

37. Wang, N., 1999. Rethinking authenticity in tourism experience. Annals of tourism research, 26(2), pp.349370. 